Research Paper

\title{
Spatial patterns of benthic bacterial communities in a large lake
}

\author{
Li-Xiang $\operatorname{Liu}^{1}$, Ming X ${ }^{1,2}$, Shuai Qiu ${ }^{1,3}$ and Rui-Chang Shen ${ }^{1,3}$ \\ ${ }^{1}$ Key Laboratory of Ecosystem Network Observation and Modeling, Institute of Geographic Sciences Natural Resources \\ Research, Chinese Academy of Sciences, Beijing, P.R. China \\ ${ }^{2}$ Department of Ecology, Evolution and Natural Resources, Rutgers University, New Brunswick, NJ, USA \\ ${ }^{3}$ University of Chinese Academy of Science, Beijing, P.R. China
}

To gain insights into the spatial pattern of microbial communities in Poyang Lake, we collected a total of 42 sediment samples from each of the four major parts of the lake in October 2010. We analyzed the spatial patterns of microbial biomass and microbial community composition using the phospholipid fatty acids (PLFA) method. The mean total microbial biomass was $2.28 \mathrm{mg}$ PLFA/kg dry weight (wt) ranging from 0.25 to $6.56 \mathrm{mg}$ PLFA/kg dry wt, indicating a high-spatial variation. The coefficients of variations ( $\mathrm{CVs}$ ) of the bacterial and fungal biomasses were 73 and $80 \%$, respectively. In addition, the CVs of biomasses for the seven bacterial groups ranged from 62 to $92 \%$, which included anaerobic bacteria, Gram-positive bacteria $(G+)$, Gram-negative bacteria $(G-)$, aerobic bacteria $(A E)$, actinomycetes $(A)$, sulfate-reducing bacteria $(S)$, and methane-oxidizing bacteria. In our study, the ammonium concentrations both in the water and in the sediment were closely correlated to the total microbial biomass and the biomasses of bacterial groups, while the ratios of fungal to bacterial biomass $(F / B)$ and $G-/ G+$ were correlated with ammonium concentration only in the water. In addition, $F / B$ in the lake sediment was significantly correlated with the nitrogen content and the ratio of organic carbon to total nitrogen contents in the sediment $(\mathrm{C} / \mathrm{N})$. Moreover, the ammonium concentrations in the water and in the sediment, water dissolved organic carbon (DOC), sediment nitrogen content, and sediment organic carbon content were strongly linked to the spatial variation of bacterial community composition. Our results show that the $\mathrm{C}$ and $\mathrm{N}$ availability in the water and in the sediment are key predictors for microbial biomass and microbial community composition in Poyang Lake.

\section{Keywords:}

lake sediment / microbial biomass / microbial community composition / PLFA / Poyang Lake
Received: January 23, 2014 Revised: March 21, 2015 Accepted: June 20, 2015

\section{Handling Editor: Helge Norf}

Correspondence: Ming Xu, Department of Ecology, Evolution and Natural Resources, Rutgers University, College Farm Road, New Brunswick, NJ 08901, USA

E-mail: mingxu@crssa.rutgers.edu

Fax: +1-973-932-8746

Abbreviations: A, actinomycetes; $A A$, anaerobic bacteria; $A E$, aerobic bacteria; $C V$, coefficients of variation; DOC, dissolved organic carbon; $\mathrm{S}$, sulfate-reducing bacteria; $\mathrm{S} / \mathrm{B}$, sulfatereducing bacteria; SOC, organic carbon in sediment; TNS, total nitrogen in sediment

\section{Introduction}

Lakes play a substantial role in the global carbon cycle by transforming organic and inorganic carbon from the surrounding terrestrial ecosystems. The high contents of organic matter and nutrients in lake sediments can support diverse microbial communities, which are critical to the biogeochemical cycles in the sediments and thus to the lake as a whole (Urakawa et al., 2000; Tong et al., 2005). In addition, many organic and inorganic pollutants are decomposed and degraded by sediment microbes (Córdova-Kreylos et al., 2006; Ferrer et al., 2011). Therefore, sediment-dwelling microbes play an important 


\section{L.-X. Liu et al.}

role in maintaining primary productivity and water quality in lake ecosystems (Chen et al., 2011).

Identifying the factors that control the microbial biomass and community composition is critical to understanding the mechanisms and processes of biogeochemical cycles in lake sediments. The microbial communities can be influenced by various factors that affect nutrient availability and thus, in turn, microbial growth. Although global distribution of microbial biomass does not show latitudinal gradients (Wardle, 1992), microbial biomass is known to be higher in marsh sediments at high-elevation sites (CórdovaKreylos et al., 2006). Some previous studies have reported correlations between microbial community compositions and the total organic carbon concentration, total nitrogen concentration, concentrations of oxygen and nitrate, redox potential (Eh), temperature, toxic metals, and $\mathrm{pH}$ in soils and sediments (Hollister et al., 2010; Nielsen et al., 2010; Seo and DeLaune, 2010). For example, Herrmann et al. (2009) found that the relative abundance of ammonia-oxidizing Archaea was positively related to the organic $\mathrm{C}$ and $\mathrm{N}$ contents in lake sediments. Moreover, total phosphorus content in the water of a boreal lake was positively correlated with microbial biomass in its sediments (Steger et al., 2011).

Although it has been reported that the variation of microbial communities in soils is generally determined by climate and physicochemical properties (Baldwin et al., 2006; Wu et al., 2009), the factors that regulate the spatial patterns of microbial communities in lake sediments are still unclear. Poyang Lake, the largest freshwater lake in China, not only provides water resources for hundreds of millions of people, but also releases large amounts of greenhouse gases (GHG) to the atmosphere (Wan et al., 2010; Liu et al., 2013). Up to now, however, only Wu et al. (2012) reported upon bacterial community compositions within four samples from Poyang Lake. Investigating the microbial community structure and its interactions with physicochemical factors at a larger scale is pivotal to understand the mechanisms of lake GHG emissions and help to improve GHG accounting and management for Poyang Lake. Therefore, the present study aims to: (1) quantify the spatial variation of the total microbial biomass and the biomasses of bacterial groups; (2) examine the spatial patterns of microbial community composition; and (3) analyze the correlations between microbial biomass, microbial community composition, and various physicochemical factors in the water and in the sediments of Poyang Lake.

\section{Materials and methods}

\subsection{Study site}

Poyang Lake $\left(\mathrm{E}^{2} 8^{\circ} 22^{\prime}-29^{\circ} 45^{\prime} \mathrm{N}, 115^{\circ} 47^{\prime}-116^{\circ} 45^{\prime} \mathrm{E}\right)$ is the largest freshwater lake in China. It is located in the middle
International Review of Hydrobiology 2015, 100, 97-105

of the Yangtze River basin in Jiangxi Province, and has a surface area of $3283 \mathrm{~km}^{2}$ and a catchment area of approximately $162000 \mathrm{~km}^{2}$ (Hu et al., 2007). The catchment features a subtropical wet climate, with a mean annual precipitation of $1680 \mathrm{~mm}$ and an annual average temperature of $17.5^{\circ} \mathrm{C}$. The lake has a maximum length of $173 \mathrm{~km}$, a maximum width of $73 \mathrm{~km}$, and a mean water level of about $13.4 \mathrm{~m}$. The mean water level in the lake fluctuates dramatically from $19.3 \mathrm{~m}$ in summer (June-August) to $8.1 \mathrm{~m}$ in winter (December-February). The Poyang Lake has been eutrophic since 1990.

\subsection{Sampling procedure}

We collected a total of 42 sediment samples from the top $15 \mathrm{~cm}$ of the sediment with a sediment sampler in four major regions of the lake, namely, the Xingzi, Wucheng, Nanjishan, and Duchang regions (hereinafter referred to as $\mathrm{X}, \mathrm{W}, \mathrm{N}$, and $\mathrm{D}$, respectively), during 16th-18th of October 2010 within the dry season (Fig. 1). The physicochemical properties and characteristics of the four regions are described in detail by Liu et al. (2013). Eight, eleven, eleven, and twelve sediment samples were obtained from the $\mathrm{N}, \mathrm{W}, \mathrm{D}$, and $\mathrm{X}$ regions, respectively (Fig. 1). All samplings were conducted within a 3 day period, in the absence of notable weather events, in order to minimize potential effects of different sampling times. Samples from each region were collected along three transects, extending from the shore to the center of the lake. Meanwhile, each sedimentary sample was a mix of three cores taken randomly within $1 \mathrm{~m}$ around the boat to assess the spatial variation of microbial communities. Samples were stored in plastic bags and ice coolers during transportation to the laboratory. Here, all samples were freeze dried and homogenized until subsampling. One subsample was frozen at $-20^{\circ} \mathrm{C}$ for PLFA analysis and the other subsample was used for determining the physicochemical properties of the sediment.

\subsection{Measurement of physicochemical properties of sediments and waters}

During field sampling, we used a tape measure to measure the water depth of each sampling site. We also collected samples of the surface water $(0-15 \mathrm{~cm})$ for chemical properties analysis. In the laboratory, $\mathrm{pH}$ of the water samples was measured with a $\mathrm{pH}$ meter (Delta 320, Mettler-Toledo, Switzerland) and electrical conductivity (EC) was measured with a conductometer (DDS-307, Jingke Rex, China). We measured dissolved organic carbon (DOC) contents of the water samples using a total organic carbon analyzer (Liqui TOC II, Elementar, Germany). Nitrate $\left(\mathrm{NO}_{3}{ }^{-}\right)$and ammonium $\left(\mathrm{NH}_{4}{ }^{+}\right)$contents in the water and the sediment samples were 


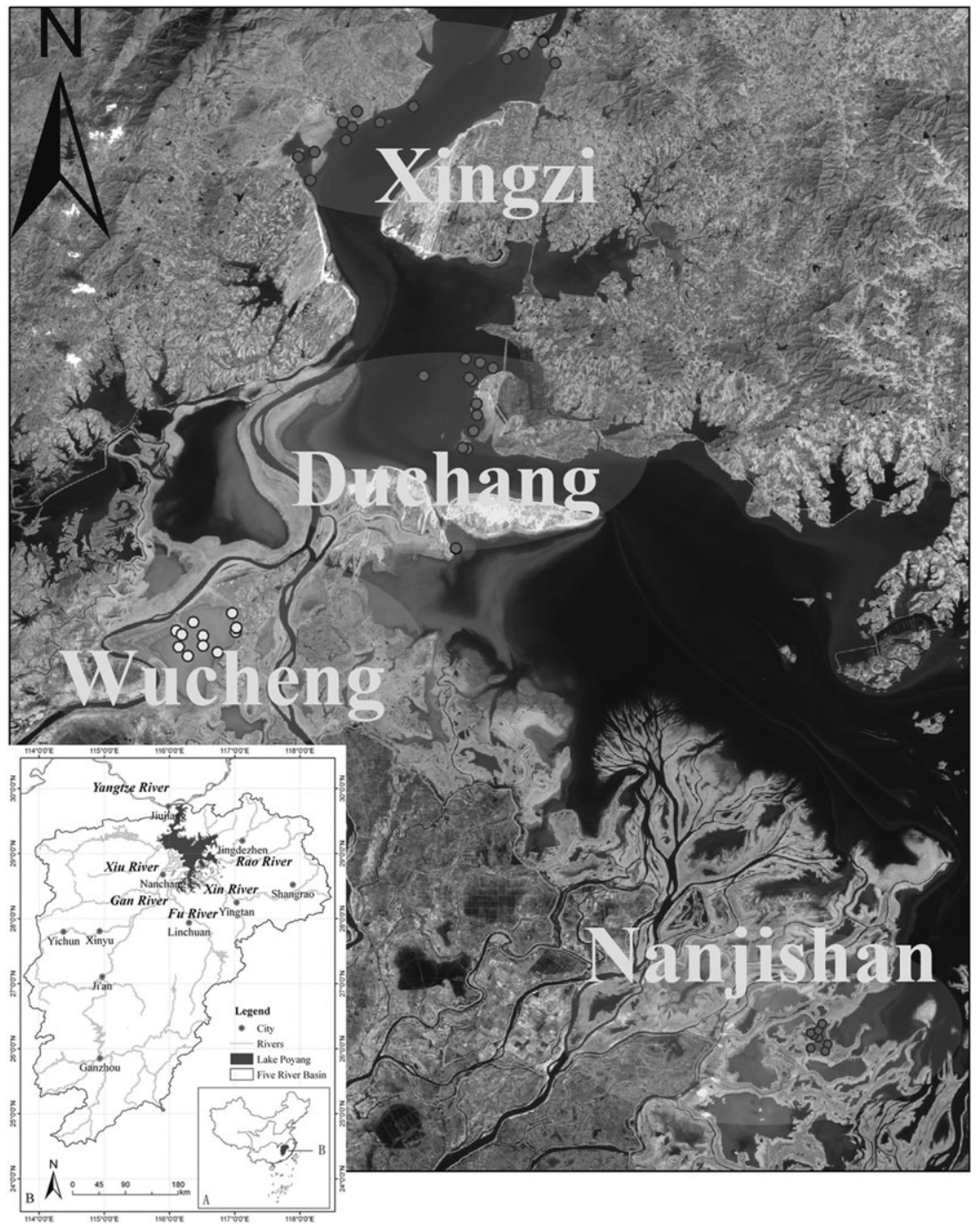

Figure 1. Locations of sampling sites in Poyang Lake. measured with a liquid chromatograph (AutoAnalyzer 3, BRAN+LUEBBE, Germany). Total nitrogen and organic carbon contents in the sediment samples were determined using a Vario Max CN Element Analyzer (NA Series 2, CE Instruments, Germany).

\subsection{PLFA analysis}

The microbial biomass and community compositions in the sediments were determined using the PLFA analysis following the method of Yu and Ehrenfeld (2010). In brief, the sediment samples were freeze dried before $5 \mathrm{~g}$ of each dry sample were extracted twice in chloroform-methanolphosphate buffer solvent. Phospholipids were then converted to fatty acid methyl esters by a mild acidic methanolysis, and were identified and quantified with a gas chromatograph (Hewlett Packard 5890 Series II; Palo Alto, CA, USA) coupled with a Sherlock Microbial
Identification System (MIDI, Inc., Newark, DE, USA). The temperature program was set at $5^{\circ} \mathrm{C} / \mathrm{min}$ from 170 to $250^{\circ} \mathrm{C}$ using hydrogen as the carrier gas. The amount of each fatty acid methyl ester identified was expressed as microgram PLFA/kg sediment dry wt by standardizing to the peak area and the amount $(5 \mu \mathrm{g})$ of the internal standard (19:0).

Fatty acid nomenclature was applied as described in previous studies (Tunlid and White, 1992; Frostegård et al., 1993). Bacteria were categorized into seven groups according to their impacts on ecosystem functions in the process of biogeochemical cycles: Gram-positive $(\mathrm{G}+)$ bacteria, Gram-negative ( $\mathrm{G}-$ ) bacteria, actinomycetes $(A)$, methanotrophs $(M)$, anaerobic bacteria $(A A)$, aerobic bacteria $(A E)$, and sulfate-reducing bacteria $(S)$. Saturated and branched-chain fatty acids (iso-, anteiso-) were represented by $\mathrm{G}+$ (Zelles, 1997; 1999). Monounsaturated straight chain and cyclopropane fatty acids were taken 


\section{L.-X. Liu et al.}

as indicators for G- (Zelles, 1997; Zogg et al., 1997; Biasi et al., 2005). A was represented by 10Me 16:0, 10Me 17:0, and 10Me 18:0 (Zelles, 1999; Frey et al., 2008). M was quantified by $18: 1 \omega 8 \mathrm{c}, 16: 1 \omega 8 \mathrm{c}, 16: 1 \omega 5 \mathrm{t}$, and $16: 1 \omega 6 \mathrm{c}$ (Nichols et al., 1985). The lipid indicators for AA and $A$ were assigned according to Vestal and White (1989) and Ben-David et al. (2011). We also assigned lipids to $S$ following Macalady et al. (2000). It should be noted that different bacteria groups mentioned above may include the same fatty acid (Ruess and Chamberlain, 2010). Fungi were quantified by $18: 1 \omega 9 c, 18: 2 \omega 6,9 c, 18: 3 \omega 6,9$, and 12c (Zogg et al., 1997; Olsson, 1999; Gray et al., 2011). In addition, we used the total content of PLFA in the sediment samples and in the microbial groups as an indicator of the biomass. The ratios of fungi-to-bacteria (F/B), Gramnegative-to-Gram-positive ( $\mathrm{G}-/ \mathrm{G}+$ ) and bacterial groupsto-bacteria were used to describe the shifts in microbial community composition (Peacock et al., 2001; Pinkart et al., 2002).

\subsection{Data analysis}

We performed a semivariogram analysis of the total microbial biomass in order to examine the spatial autocorrelation among sampling points. We performed a one-way ANOVA followed by a post hoc Tukey's test to calculate the differences in the biomasses of the seven bacterial groups, $\mathrm{G}-/ \mathrm{G}+$, and $\mathrm{F} / \mathrm{B}$ among the four regions of the lake. The standard deviation and coefficient of variation (CV) were used as proxies for the spatial variation in microbial biomass. We also made correlation analysis between the physicochemical properties and microbial community indicators, such as microbial biomass and microbial community composition in the lake sediment. All statistical analyses were performed with the SPSS 17.0 statistical software (SPSS, Inc., Chicago, USA). Graphs were made with the Sigma Plot 11.0 program (Systat Software, Inc., San Jose, CA, USA).

\section{Results}

\subsection{Microbial biomass}

Our result revealed no spatial autocorrelation among the data points by the semivariogram analysis (data not shown), so we treated all sampling points as independent samples.

The total content of PLFA in the top $15 \mathrm{~cm}$ of the Poyang Lake sediments used as an indicator of microbial biomass ranged from 0.25 to $6.56 \mathrm{mg}$ PLFA/kg dry wt. The total microbial biomass showed no significant differences between the four regions of the lake $(p>0.10)$. However, we found a general decreasing trend from the north to the south of the lake. Specifically, the highest mean microbial biomass was observed in the $\mathrm{W}$ region, followed by the $\mathrm{D}$, $\mathrm{X}$, and $\mathrm{N}$ region in decreasing order, but the largest mean $\mathrm{CV}$ for total microbial biomass was observed in the $\mathrm{X}$ region, followed by the $\mathrm{W}, \mathrm{D}$, and $\mathrm{N}$ region in decreasing order, indicating high-spatial variation (Fig. 2).

We found high-spatial variation of the bacterial and fungal biomasses in the lake. PLFA contents of bacteria and fungi were $1.40 \pm 1.02$ and $0.15 \pm 0.12 \mathrm{mg}$ PLFA $/ \mathrm{kg}$ dry wt, respectively (mean \pm standard deviation), reflecting a contribution of 59 and $7 \%$, respectively, to the total microbial biomass in the lake. CVs were $73 \%$ for bacteria and $80 \%$ for fungi. Both mean bacterial biomass and mean fungal biomass were the highest in the $\mathrm{W}$ region and the lowest in the $\mathrm{N}$ region (Fig. 2).

Respective to the bacterial groups, the biomasses of the $A A, G+, G-, A E, A, S$, and methane-oxidizing bacteria were $1.08,0.84,0.38,0.35,0.14,0.16$, and $0.13 \mathrm{mg}$ PLFA/kg dry wt, respectively (Fig. 3), accounting for 47 , $37,17,15,6,7$, and $6 \%$ of the total bacterial biomass, respectively. The CVs of the seven bacterial groups were $62,82,92,71,86,88$, and $77 \%$, respectively (Fig. 3). In general, our results showed high-spatial variations of the microbial biomass for the seven bacterial groups among the four regions. It should be noted that the differences in the biomasses of the $G-, A E, S$, and $A A$ were not significant according to the post hoc multiple comparisons $(p=0.08)$, whereas there were significant differences among the biomasses of other bacterial groups $(p<0.05)$ (Table 1). On the whole, the overlap of the seven bacterial groups did not influence our findings.

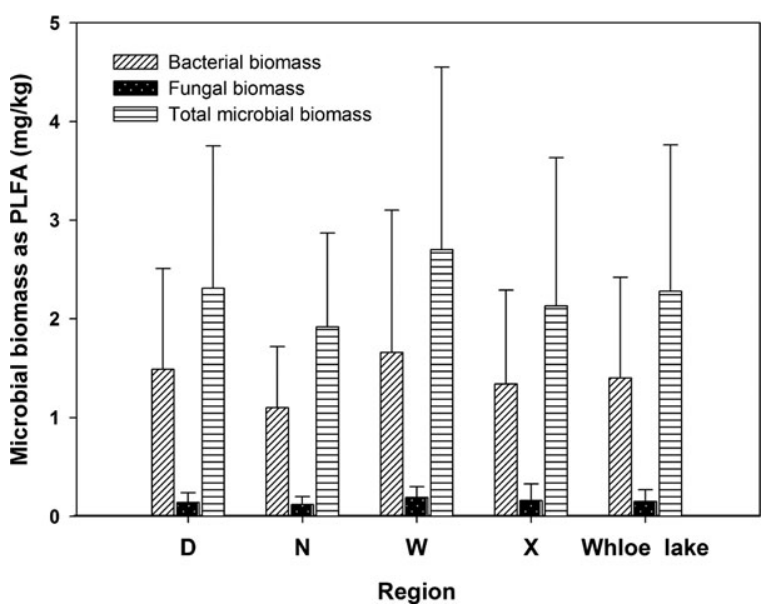

Figure 2. Spatial variation of total microbial biomass, bacterial, and fungal biomass (mg PLFA/kg dry wt, $N=42$ ) in the four regions and in Poyang Lake (D, Duchang; N, Nanjishan; W, Wucheng; $X$, Xingzi; Poyang Lake, the mean biomass of the four regions). 


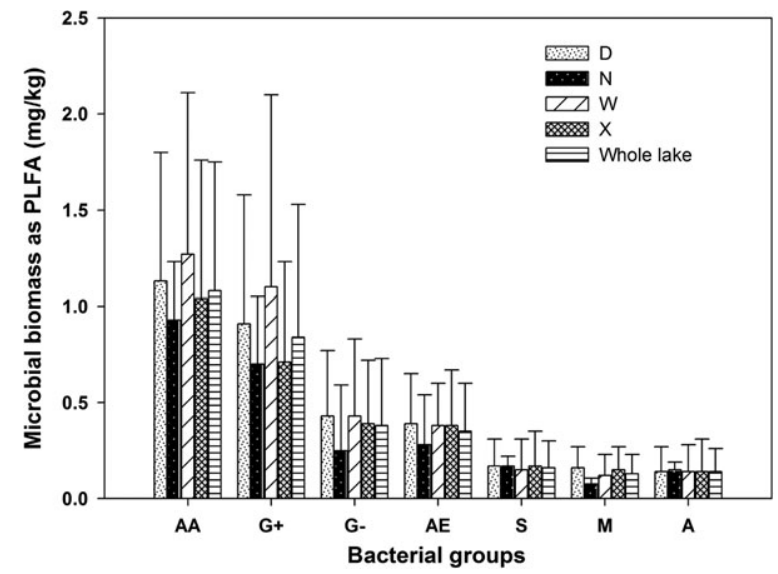

Figure 3. Mean microbial biomass of bacterial groups in Poyang Lake (AA, anaerobic bacteria; $\mathrm{G}+$, Gram-positive bacteria; $\mathrm{G}-$, Gram-negative bacteria; $A E$, aerobic bacteria; $S$, sulfate-reducing bacteria; $A$, actinomycetes; M, methanotrophs; other abbreviations as in Fig. 2).

\subsection{Microbial community composition}

The mean ratios of $\mathrm{F} / \mathrm{B}$ and $\mathrm{G}-/ \mathrm{G}+$ in Poyang Lake were $0.16 \pm 0.10$ and $0.42 \pm 0.17$, respectively (mean \pm standard deviation). Although there were slight differences in F/B among the four regions, the differences were not statistically significant $(p>0.05)$ (Table 2$)$. In contrast, the ratio of $\mathrm{G}-/ \mathrm{G}+$ was significantly higher in the $\mathrm{X}$ region than the $\mathrm{W}$ and $\mathrm{N}$ regions $(p<0.01)$, whereas the differences between $X$ and $D$ were significant at $90 \%$ confidence level according to the post hoc multiple comparisons $(p=0.08)$ (Table 2). Moreover, there were significant differences for the $\mathrm{G}$ - to bacterial biomass ratio between the $\mathrm{X}$ region and the $\mathrm{N}, \mathrm{W}$ regions (Table 2 ). And we did not found any

Table 1. Mean biomass for bacterial groups in Poyang Lake

\begin{tabular}{ll}
\hline Bacterial groups & $\begin{array}{c}\text { Biomass } \\
(\mathrm{mg} \text { PLFA/kg dry wt) }\end{array}$ \\
\hline Anaerobic bacteria & $1.08 \pm 0.67 \mathrm{a}$ \\
Aerobic bacteria & $0.35 \pm 0.25 \mathrm{c}$ \\
Gram-positive bacteria & $0.84 \pm 0.69 \mathrm{~b}$ \\
Gram-negative bacteria & $0.38 \pm 0.35 \mathrm{c}$ \\
Methanotrophs & $0.13 \pm 0.10 \mathrm{e}$ \\
Sulfate-reducing bacteria & $0.16 \pm 0.14 \mathrm{~d}$ \\
Actinomycetes & $0.14 \pm 0.12 \mathrm{~d}$
\end{tabular}

Data are presented as the mean \pm standard deviation; different letters indicate significant differences between bacterial groups (one-way ANOVA, post hoc Tukey's test, $N=42, p<0.05)$.
Table 2. Ratios of $G-/ G+$ and $F / B$ in different regions of the lake

\begin{tabular}{llcl}
\hline & \multicolumn{1}{c}{$\mathrm{G}-/ \mathrm{G}+$} & $\mathrm{F} / \mathrm{B}$ & \multicolumn{1}{c}{$\mathrm{G}-/ \mathrm{B}$} \\
\hline Duchang & $0.47 \pm 0.12 \mathrm{bc}$ & $0.14 \pm 0.09$ & $0.30 \pm 0.05 \mathrm{ab}$ \\
Nanjishan & $0.36 \pm 0.19 \mathrm{~b}$ & $0.14 \pm 0.09$ & $0.21 \pm 0.10 \mathrm{~b}$ \\
Wucheng & $0.39 \pm 0.17 \mathrm{~b}$ & $0.18 \pm 0.12$ & $0.27 \pm 0.10 \mathrm{~b}$ \\
Xingzi & $0.55 \pm 0.14 \mathrm{a}$ & $0.17 \pm 0.10$ & $0.32 \pm 0.08 \mathrm{a}$ \\
Whole lake & $0.42 \pm 0.17$ & $0.16 \pm 0.10$ & $0.28 \pm 0.09$ \\
\hline
\end{tabular}

G-/G+, Gram-negative bacteria/Gram-positive bacteria; F/B, fungi/bacteria; G-/B, Gram-negative bacteria/ bacteria.

Data are presented as the mean \pm standard deviation; different letters indicate significant differences between the sampling sites (one-way ANOVA, post hoc Tukey's test, $p<0.05) ; N=42$.

significant difference for the other six bacterial groups to bacterial biomass ratios.

\subsection{Effects of physicochemical properties on microbial communities}

Significant relationships have been identified between the physicochemical properties of the water and the sediment and microbial biomass (total microbial biomass and the biomasses of microbial groups) in the sediment. In particular, we found that the $\mathrm{NH}_{4}{ }^{+}$concentrations both in the water and in the sediment were highly correlated with the microbial biomass in Poyang Lake. In correlation analysis, the sediment $\mathrm{NH}_{4}{ }^{+}$concentration was found to be positively correlated with the total microbial biomass ( $p<0.05, r=0.35$ ), but also the biomasses of the bacteria, $\mathrm{G}+, \mathrm{AA}$, and $\mathrm{AE}(p<0.05, r=0.33,0.34,0.31$, and 0.39, respectively). The water $\mathrm{NH}_{4}{ }^{+}$concentration was exclusively positively correlated with the biomass of the methanotrophs $(p<0.05, r=0.32)$ (Table 3$)$. And the sediment organic carbon content was positively correlated with the biomasses of the actinomycetes, methanotrophs, and sulfate-reducing bacteria $(p<0.05, r=0.35,0.39$, 0.38 , respectively) (Table 3 ). Furthermore, water depth was found to be negatively correlated with the biomasses of the actinomycetes and sulfate-reducing bacteria ( $p<0.05, r=0.39$ and 0.38 , respectively).

In addition to microbial biomass, we also found significant correlations between the physicochemical properties of the water and the sediment and the microbial community composition. The F/B ratio was significantly correlated with the water $\mathrm{NH}_{4}{ }^{+}$concentration $(p<0.05$, $r=0.33$ ), and was also strongly correlated with the sediment nitrogen content (Table 3 ) and the sediment $\mathrm{C} / \mathrm{N}$ ratio ( $p<0.01, r=0.44$ and 0.83 , respectively) (Fig. 4). The $\mathrm{G}-/ \mathrm{G}+$ and $\mathrm{G}-/$ bacteria ratios were positively 
Table 3. Pearson correlation coefficients between microbial biomass and physicochemical properties

\begin{tabular}{|c|c|c|c|c|}
\hline Biomass of bacterial groups & Water depth & Water $\mathrm{NH}_{4}^{+}$ & Sediment $\mathrm{NH}_{4}^{+}$ & $\begin{array}{c}\text { Organic carbon } \\
\text { in sediment }\end{array}$ \\
\hline Total microbial biomass & -0.022 & 0.064 & $0.35^{*}$ & 0.13 \\
\hline $\mathrm{G}+$ & 0.094 & -0.033 & $0.34^{*}$ & 0.008 \\
\hline $\mathrm{G}-$ & 0.055 & 0.13 & 0.30 & 0.099 \\
\hline Bacteria & 0.082 & 0.023 & $0.33^{*}$ & 0.039 \\
\hline Fungi & -0.25 & 0.091 & 0.19 & 0.19 \\
\hline Actinomycetes & $-0.39^{*}$ & 0.10 & 0.17 & $0.35^{*}$ \\
\hline Methanotrophs & -0.13 & $0.32^{*}$ & 0.22 & $0.39^{*}$ \\
\hline Anaerobic bacteria & -0.13 & 0.098 & $0.39^{*}$ & 0.28 \\
\hline Aerobic bacteria & -0.11 & 0.19 & $0.31^{*}$ & 0.25 \\
\hline Sulfate-reducing bacteria & $-0.38^{*}$ & 0.15 & 0.18 & $0.38^{*}$ \\
\hline
\end{tabular}

G-, Gram-negative bacteria; $\mathrm{G}+$, Gram-positive bacteria.

Asterisks indicate statistically significant correlations $\left({ }^{*} p<0.05\right)$.

correlated with the water $\mathrm{NH}_{4}{ }^{+}$and $\mathrm{NO}_{3}{ }^{-}$concentrations, but were negatively correlated with the water DOC content (Table 4). In contrast, the $\mathrm{G}+$ /bacteria ratio was negatively correlated with the water $\mathrm{NH}_{4}{ }^{+}$and $\mathrm{NO}_{3}{ }^{-}$concentrations ( $p<0.01, r=-0.42$ and -0.44 , respectively), but was positively correlated with the water DOC content $(p<0.01$, $r=0.53$ ). The correlations between the actinomycetes/ bacteria ratio and water depth and the sediment organic carbon content were significant $(p<0.05, r=-0.35$ and 0.37 , respectively). Significant correlations were found between the methanotrophs/bacteria ratio and the water $\mathrm{NH}_{4}{ }^{+}$and water $\mathrm{NO}_{3}{ }^{-}$concentrations $(p<0.05, r=0.35$ and 0.40 , respectively). We also found significant correlations between the anaerobic bacteria/bacteria ratio and the sediment total nitrogen content, between the aerobic bacteria/bacteria ratio and the water DOC content, and

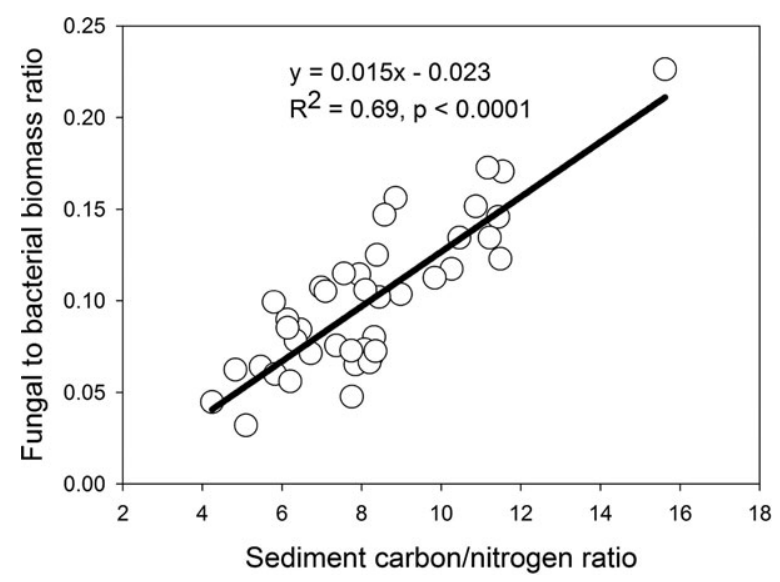

Fig. 4. Relationship between the ratio of $F / B$ and the sediment $\mathrm{C} / \mathrm{N}$ ratio $(\mathrm{F} / \mathrm{B}$, the ratios of fungal to bacterial biomass; sediment $\mathrm{C} / \mathrm{N}$ ratio, the ratio of organic carbon to total nitrogen contents in the sediment). between the sulfate-reducing bacteria/bacteria ratio and the sediment organic carbon content (Table 4).

\section{Discussion}

\subsection{Microbial biomass}

The spatial variability of the total microbial biomass in Poyang Lake was moderately high in comparison with many other boreal lakes and freshwater and coastal systems. The mean total microbial biomass $(2.28 \pm 1.48 \mathrm{mg}$ PLFA $/ \mathrm{kg}$ dry $\mathrm{wt})$ was within the range of 0.3-33.3 mg PLFA/kg dry wt reported in previous studies (Mancuso et al., 1990; Bowman et al., 2003; Harji et al., 2010). On the other hand, the ratio of maximum to minimum of the total microbial biomass in Poyang Lake was 26.2, which was much higher than those reported in other boreal, temperate lakes, streams, and coastal ecosystems (1.3-20.4) (Smoot and Findlay, 2001; BenDavid et al., 2004; Steger et al., 2011), but was obviously lower than the value of 111 that was found in the Visakhapatnam Harbor in India (Harji et al., 2010). Moreover, the CV of total microbial biomass in Poyang Lake was $65 \%$, which was slightly higher than that of the surface layer in Antarctic Continental Shelf Sediments (61\%) (Bowman et al., 2003) and the Hiroshima Bay in Japan during autumn (62\%) (Rajendran and Nagatomo, 1999), but it was much lower than that of the Hiroshima Bay in Japan during spring (150\%) (Rajendran and Nagatomo, 1999) and the Suo Nada of the Seto Inland Sea in spring (211\%) and in summer (100\%) (Rajendran and Nagatomo, 1999). Because only a few studies have so far reported microbial biomasses in lake sediments, the possibilities for comparison with other regions are limited. 
Table 4. Pearson correlation coefficients between microbial composition and physicochemical properties

\begin{tabular}{|c|c|c|c|c|c|c|c|}
\hline $\begin{array}{l}\text { Microbial community } \\
\text { composition }\end{array}$ & $\begin{array}{l}\text { Water } \\
\text { depth }\end{array}$ & $\begin{array}{l}\text { Water } \\
\mathrm{NO}_{3}^{-}\end{array}$ & $\begin{array}{l}\text { Water } \\
\mathrm{NH}_{4}^{+}\end{array}$ & TNS & $\begin{array}{l}\text { Water } \\
\text { DOC }\end{array}$ & SOC & $\begin{array}{c}\text { Sedimentary } \\
\mathrm{C} / \mathrm{N}\end{array}$ \\
\hline $\mathrm{G}-/ \mathrm{G}+$ & 0.1 & $0.40^{* *}$ & $0.44^{* *}$ & 0.01 & $-0.49^{* *}$ & 0.092 & 0.14 \\
\hline Fungi/bacteria & 0.13 & $0.33^{*}$ & -0.04 & $0.44^{* *}$ & 0.18 & -0.084 & $0.83^{* *}$ \\
\hline $\mathrm{G}+/$ bacteria & -0.14 & $-0.44^{*}$ & $-0.42^{*}$ & 0.02 & $0.53^{*}$ & -0.058 & -0.14 \\
\hline G-/bacteria & 0.14 & $0.44^{*}$ & $0.42^{*}$ & -0.02 & $-0.53^{*}$ & 0.058 & 0.14 \\
\hline Actinomycetes/bacteria & $-0.35^{*}$ & -0.19 & -0.11 & 0.28 & 0.27 & $0.37^{*}$ & -0.068 \\
\hline Methanotrophs/bacteria & 0.061 & $0.35^{*}$ & $0.40^{*}$ & 0.045 & -0.33 & 0.11 & 0.3 \\
\hline $\mathrm{AA} / \mathrm{B}$ & -0.23 & -0.026 & -0.043 & $0.26^{*}$ & 0.081 & 0.2 & 0.015 \\
\hline $\mathrm{AE} / \mathrm{B}$ & -0.001 & 0.25 & 0.27 & 0.097 & $-0.37^{*}$ & 0.064 & 0.1 \\
\hline S/B & -0.32 & -0.077 & -0.01 & 0.24 & 0.21 & $0.38^{*}$ & -0.005 \\
\hline
\end{tabular}

$\mathrm{AA} / \mathrm{B}$, anaerobic bacteria/bacteria; $\mathrm{AE} / \mathrm{B}$, aerobic bacteria/bacteria, $\mathrm{S} / \mathrm{B}$, sulfate-reducing bacteria/bacteria; TNS, total nitrogen in sediment; SOC, organic carbon in sediment.

Asterisks indicate statistically significant correlations $\left({ }^{*} p<0.05 ;{ }^{* *} p<0.01\right)$.

The biomasses of the seven bacterial groups in Poyang Lake showed high-spatial variation between the four regions. Bacterial community compositions are relevant for the GHG fluxes (Balser and Firestone, 2005; Gutierrez et al., 2013; Li et al., 2013). However, no relationship was found here between bacteria communities and $\mathrm{CO}_{2}$ flux probably due to the high-functional redundancy of bacteria in the process of $\mathrm{CO}_{2}$ production (Allison and Martiny, 2008). Our earlier findings have shown that the average minimum flux of $\mathrm{CO}_{2}$ occurred in the $W$ region (Liu et al., 2013), whereas the average maximum $\mathrm{CO}_{2}$ fluxes in the other three regions were similar. Opposed to the average maximum $\mathrm{CO}_{2}$ flux, the mean bacterial biomass was highest in the $\mathrm{W}$ region. Earlier studies have shown that the $\mathrm{CH}_{4}$ efflux was positively related to methanogenic biomass (Urbanová et al., 2010; Gutierrez et al., 2013), but negatively related to methanotrophic biomass (Yavitt et al., 2012; Nazaries et al., 2013). However, it was found in an earlier study that the average minimum and maximum fluxes of $\mathrm{CH}_{4}$ occurred in the $W$ and $D$ regions, respectively (Liu et al., 2013). In our study the average minimum and maximum biomasses of methanotrophs occurred in the $N$ and $D$ regions, respectively. Moreover, previous studies have reported associations between sulfate-reducing bacteria, $\mathrm{G}-$ and $\mathrm{G}+$ and $\mathrm{N}_{2} \mathrm{O}$ flux (Balser and Firestone, 2005; Ontiveros-Valencia et al., 2012; Li et al., 2013). Our previous study has shown that the average minimum and maximum fluxes of $\mathrm{N}_{2} \mathrm{O}$ were in the $\mathrm{D}$ and $\mathrm{W}$ regions, respectively (Liu et al., 2013). On the contrary, in the current study the average maximum sulfate-reducing bacteria and the average minimum $\mathrm{G}+$ occurred in the $\mathrm{W}$ region, whereas the mean maximum biomasses of $\mathrm{G}-$, $A E$, and methanotrophs occurred in the $D$ region. The above-mentioned results may indicate a controversial relationship between the seven bacterial groups and greenhouse gas fluxes. Further investigation is required to address this issue.

\subsection{Effect of substrate availability on microbial communities in lake sediments}

In the present study, the mean organic carbon content, total nitrogen content and $\mathrm{C} / \mathrm{N}$ ratio in the sediment were 0.70 , 0.088 , and $8.20 \%$, respectively. We found these factors to significantly affect the microbial communities in Poyang Lake. Previous studies suggested that microbes use organic carbon as their main energy source while $\mathrm{N}$ is assimilated and metabolized during microbial growth as well as during the decomposition of the organic matter in the process of GHG production (Mohanty et al., 2013). Lin et al. (2011) have found that $\mathrm{NH}_{4}{ }^{+}$in water and in sediment could influence microbial processes at the sediment-water interface. Gardner et al. (2004) also reported that $\mathrm{NH}_{4}{ }^{+}$in water and in sediment might affect organic matter decomposition by bacteria at the deepest layer of water in Lake Michigan. In our study, the $F / B$ ratio was positively and linearly related with the sediment $\mathrm{C} / \mathrm{N}$ ratio. Previous studies showed that high $\mathrm{C} /$ $\mathrm{N}$ ratio in soil could stimulate fungal growth, while low $\mathrm{C} / \mathrm{N}$ ratio in soil could encourage bacterial growth (Henriksen and Breland, 1999; Vinten et al., 2002). This is supported by the fact that fungal growth requires a greater amount of carbon, whereas bacteria require a higher level of nitrogen in soil (Dong and DeLaune, 2010), thus increasing the F/B ratio along with the rise of C/N ratio (Henriksen and Breland, 1999; Vinten et al., 2002). This finding agree with the previous studies by Strickland and Rousk (2010) and Waring et al. (2013). Finally, our earlier study found that the sediment C and $\mathrm{N}$ contents, sediment $\mathrm{C} / \mathrm{N}$ ratio and $\mathrm{NH}_{4}{ }^{+}$in water were the controlling factors of GHG fluxes at the study site (Liu et al., 2013), while our present study now shows that these factors are also related to $\mathrm{F} / \mathrm{B}, \mathrm{G}-/ \mathrm{G}+$, and bacterial 
composition. Further work is required to elucidate the mechanism of how microbial communities affected the spatial variation of GHG fluxes in Poyang Lake.

\section{Conclusions}

Not only the total microbial biomass but also the biomasses of the microbial groups in the sediment showed high-spatial variation in Poyang Lake. The CV of the total microbial biomass in the sediment was $65 \%$ in Poyang Lake. The CVs of biomasses for the bacteria, fungi, and seven bacterial groups was of wide range, from 62 to $90 \%$. In addition, the $\mathrm{G}-/ \mathrm{G}+$ and $\mathrm{G}-$ /bacteria ratios showed high-regional variations. The sediment organic carbon content, $\mathrm{NH}_{4}{ }^{+}$contents in the water and in the sediment and water depth significantly influenced the spatial variation of microbial biomass. Apart from microbial biomass, there were high correlations between microbial community composition and water depth, $\mathrm{NH}_{4}{ }^{+}$contents in the water and in the sediment, sediment organic carbon content, sediment total nitrogen content, water DOC content, and sediment $\mathrm{C} / \mathrm{N}$ ratio. These results well explained the high-spatial variation of GHG emissions in the Poyang Lake as revealed in our earlier studies.

This research was supported by the EcosystemAtmosphere Exchanges of $\mathrm{C}$ - and N-Gases: Processes and Principles for Good Management at Catchment Scale, China (no. 2012CB417103), Assessment and Valuation of Ecosystem Services in Qinghai Provincem, China (no. 2013-N-556). We gratefully acknowledge the Poyang Lake Laboratory Wetland Ecosystem Research, CAS for permission to access the study sites, and assistance with field campaign. We also thank Min Wang and Mao Lin for helping in PLFA experiments at Xiamen.

\section{References}

Allison, S. D., Martiny, J. B. H. 2008: Resistance, resilience, and redundancy in microbial communities. PNAS 105, 1151211519.

Baldwin, D. S., Rees, G. N., Mitchell, A. M., Watson, G., Williams, J. 2006: The short-term effect of salinization on anaerobic nutrient cycling and microbial community structure in sediment from a freshwater wetland. Wetlands 26, 455-464.

Balser, T. C., Firestone, M. K. 2005: Linking microbial community composition and soil processes in a California annual grassland and mixed-conifer forest. Biogeochemistry 73, 395-415.

Ben-David, E. A., Holden, P. J., Stone, D. J. M., Harch, B. D., Foster, L. J. 2004: The use of phospholipids fatty acid analysis to measure impact of acid rock drainage on microbial communities in sediments. Microb. Ecol. 48, 300-315.

Ben-David, E. A., Zaady, E. L., Sher, Y. N., Nejidat, A. 2011: Assessment of the spatial distribution of soil microbial communities in patchy arid and semi-arid landscapes of the Negev Desert using combined PLFA and DGGE analyses. FEMS Microbiol. Ecol. 76, 492-503.

Biasi, C., Rusalimova, O., Meyer, H., Kaiser, C., et al. 2005: Temperature-dependent shift from labile to recalcitrant carbon sources of arctic heterotrophs. Rapid Commun. Mass Spectrom. 19, 1401-1408.

Bowman, J. P., McCammon, S. A., Gibson, J. A. E., Robertson, L., Nichols, P. D. 2003: Prokaryotic metabolic activity and community structure in Antarctic continental shelf sediments. Appl. Environ. Microbiol. 69, 2448-2462.

Chen, K., Yao, J., Qi, S. H., Zheng, S. X., et al. 2011: Characterization of depth related microbial community activities in freshwater sediment by combined method. Geomicrobiol. J. 28, 328-334.

Córdova-Kreylos, A. L., Cao, Y. P., Green, P. G., Hwang, H. M., et al. 2006: Diversity, composition, and geographical distribution of microbial communities in California salt marsh sediments. Appl. Environ. Microbiol. 72, 3357-3366.

Dong, C. S., DeLaune, R. D. 2010: Effect of redox conditions on bacterial and fungal biomass and carbon dioxide production in Louisiana coastal swamp forest sediment. Sci. Total Environ. 408, 3623-3631.

Ferrer, M., Guazzaroni, M. E., Richter, M., García-Salamanca, A., et al. 2011: Taxonomic and functional metagenomic profiling of the microbial community in the anoxic sediment of a subsaline shallow lake (Laguna de Carrizo, Central Spain). Microb. Ecol. 62, 824-837.

Frey, S. D., Drijber, R., Smith, H., Melillo, J. 2008: Microbial biomass, functional capacity, and community structure after 12 years of soil warming. Soil Biol. Biochem. 40, 29042907.

Frostegård, Å., Tunlid, A., Bååth, E. 1993: Phospholipid fatty acid composition, biomass, and activity of microbial communities from two soil types experimentally exposed to different heavy metals. Appl. Environ. Microbiol. 59, 3605-3617.

Gardner, W. S., Lavrentyev, P. J., Cavaletto, J. F., McCarthy, M. J., et al. 2004: Distribution and dynamics of nitrogen and microbial plankton in southern Lake Michigan during spring transition 1999-2000. J. Geophys. Res. 109, 1-16.

Gray, S. B., Classen, A. T., Kardol, P., Yermakov, Z., Miller, R. M. 2011: Multiple climate change factors interact to alter soil microbial community structure in an old-field ecosystem. Soil Sci. Soc. Am. J. 75, 2217-2226.

Gutierrez, J., Kim, S. Y., Kim, P. J. 2013: Effect of rice cultivar on $\mathrm{CH}_{4}$ emissions and productivity in Korean paddy soil. Field. Crop. Res. 146, 16-24.

Harji, R. R., Bhosle, N. B., Garg, A., Sawant, S. S., Venkat, K. 2010: Sources of organic matter and microbial community structure in the sediments of the Visakhapatnam harbour, east coast of India. Chem. Geol. 276, 309-317.

Henriksen, T. M., Breland, T. A. 1999: Nitrogen availability effects on carbon mineralization, fungal and bacterial growth, and enzyme activities during decomposition of wheat straw in soil. Soil Biol. Biochem. 31, 1121-1134.

Herrmann, M., Saunders, A. M., Schramm, A. 2009: Effect of lake trophic status and rooted macrophytes on community composition and abundance of ammonia-oxidizing prokaryotes in freshwater sediments. Appl. Environ. Microbiol. 75, 3127-3136.

Hollister, E. B., Engledow, A. S., Hammett, A. J. M., Provin, T. L., et al. 2010: Shifts in microbial community structure along an ecological gradient of hypersaline soils and sediments. ISME J. 4, 829-838. 
Hu, Q., Feng, S., Guo, H., Chen, G. Y., Jiang, T. 2007: Interactions of the Yangtze river flow and hydrologic processes of the Poyang Lake, China. J. Hydrol. 347, 90-100.

Li, Y., Zhang, X., Zhou, L. H., Ren, J. K., Zhao, N. 2013: The study on the inhibiting effect of denitrifying bacteria on sulfatereducing process. Appl. Mech. Mater. 260, 1210-1214.

Lin, X., McCarthy, M. J., Carini, S. A., Gardner, W. S. 2011: Net, actual, and potential sediment-water interface $\mathrm{NH}_{4}{ }^{+}$fluxes in the northern Gulf of Mexico (NGOMEX): Evidence for $\mathrm{NH}_{4}^{+}$ limitation of microbial dynamics. Cont. Shelf Res. 31, 120-128.

Liu, L. X., Xu, M., Lin, M., Zhang, X. 2013: Spatial variability of greenhouse gas effluxes and their controlling factors in the Poyang Lake in China. Pol. J. Environ. Stud. 22, 749-758.

Macalady, J. L., Mack, E. E., Nelson, D. C., Scow, K. M. 2000: Sediment microbial community structure and mercury methylation in mercury-polluted Clear Lake, California. Appl. Environ. Microb. 66, 1479-1488.

Mancuso, C. A., Franzmann, P. D., Burton, H. R., Nichols, P. D. 1990: Microbial community structure and biomass estimates of a methanogenic Antarctic lake ecosystem as determined by phospholipid analyses. Microb. Ecol. 19, 73-95.

Mohanty, M., Sinha, N. K., Reddy, K. S., Chaudhary, R. S., et al. 2013: How important is the quality of organic amendments in relation to mineral $\mathrm{N}$ availability in soils? Agric. Res. 2, 99-110.

Nazaries, L., Pan, Y., Bodrossy, L., Baggs, E. M., et al. 2013: Evidence of microbial regulation of biogeochemical cycles from a study on methane flux and land use change. Appl. Environ. Microbiol. 79, 4031-4040.

Nichols, P. D., Smith, G. A., Antworth, C. P., Hanson, R. S., et al. 1985: Phospholipid and lipopolysaccharide normal and hydroxy fatty acids as potential signatures for methaneoxidizing bacteria. FEMS Microbiol. Lett. 31, 327-335.

Nielsen, U. N., Osler, G. H. R., Campbell, C. D., Burslem, D. F. R. P., René van der W., 2010: The influence of vegetation type, soil properties and precipitation on the composition of soil mite and microbial communities at the landscape scale. $J$. Biogeogr. 37, 1317-1328.

Olsson, P. A. 1999: Signature fatty acids provide tools for determination of the distribution and interactions of mycorrhizal fungi in soil. FEMS Microbiol. Ecol. 29, 303-310.

Ontiveros-Valencia, A., Ziv-El, M., Zhao, H. P., Feng, L., et al. 2012: Interactions between nitrate-reducing and sulfatereducing bacteria coexistingina hydrogen-fed biofilm. Environ. Sci. Technol. 46, 11289-11298.

Peacock, A. D., Mullen, M. D., Ringelberg, D. B., Tyler, D. D., et al. 2001: Soil microbial community responses to dairy manure or ammonium nitrate applications. Soil. Biol. Biochem. 33, 1011-1019.

Pinkart, H. C., Ringelberg, D. B., Piceno, Y. M., Macnaughton, S. J., White, D. C. 2002: in: Hurst, C. J., Crawford, R. L., Knudsen, G. R., Mclnerney, M. J., Stetzenbach, L.D.(eds.), Manual of Environmental Microbiology. American Society for Microbiology Press, Washington DC, pp. 101-113.

Rajendran, N., Nagatomo, Y. 1999: Seasonal changes in sedimentary microbial communities of two eutrophic bays as estimated by biomarkers. Hydrobiologia 393, 117-125.

Ruess, L., Chamberlain, P. M. 2010: The fat that matters: Soil food web analysis using fatty acids and their carbon stable isotope signature. Soil Biol. Biochem. 42, 1898-1910.

Seo, D. C., DeLaune, R. D. 2010: Effect of redox conditions on bacterial and fungal biomass and carbon dioxide production in Louisiana coastal swamp forest sediment. Sci. total Environ. 408, 3623-3631.
Smoot, J. C., Findlay, R. H. 2001: Spatial and seasonal variation in a reservoir sedimentary microbial community as determined by phospholipid analysis. Microb. Ecol. 42, 350-358.

Steger, K., Premke, K., Gudasz, C., Sundh, I., Tranvik, L. J. 2011: Microbial biomass and community composition in boreal lake sediments. Limnol. Oceanogr. 56, 725-733.

Strickland, M. S., Rousk, J. 2010: Considering fungal: Bacterial dominance in soils-Methods, controls, and ecosystem implications. Soil Biol. Biochem. 42, 1385-1395.

Tong, Y., Lin, G. F., Ke, X., Liu, F. P., et al. 2005: Comparison of microbial community between two shallow freshwater lakes in middle Yangtze basin, East China. Chemosphere 60, 85-92.

Tunlid, A., White, D. C. 1992: in: Stotzky, G., Bollag, J. M.(eds.), Soil Biochemistry 7. Dekker, New York, pp. 229-261.

Urakawa, H., Yoshida, T., Nishimura, M., Ohwada, K. 2000: Characterization of depth-related population variation in microbial communities of a coastal marine sediment using $16 S$ rDNA-based approaches and quinine profiling. Environ. Microbiol. 2, 542-554.

Urbanová, Z., Bárta, J., Picek, T. 2013: Methane emissions and methanogenic archaea on pristine, drained and restored mountain peatlands, Central Europe. Ecosystems 16, 664-677.

Vestal, J. R., White, D. C. 1989: Lipid analysis in microbial ecology-quantitative approaches to the study of microbial communities. Bioscience 39, 535-541.

Vinten, A. J. A., Whitmore, A. P., Bloem, J., Howard, R., Wright, F. 2002: Factors affecting $\mathrm{N}$ immobilisation/mineralisation kinetics for cellulose-, glucose- and straw-amended sandy soils. Biol. Fertil. Soils. 36, 190-199.

Wan, H. X., Qin, Z. H., Liu, Y. B., Xu, Y. M. 2010: Estimates of carbon fluxes from Poyang Lake wetlands vegetation in the growing season. P. SPIE 7858, 1-10.

Wardle, D. A. 1992: A comparative assessment of factors which influence microbial biomass carbon and nitrogen levels in soil. Biol. Rev. 67, 321-358.

Waring, B. G., Averill, C., Hawkes, C. V. 2013: Differences in fungal and bacterial physiology alter soil carbon and nitrogen cycling: Insights from meta-analysis and theoretical models. Ecol. Lett. 16, 887-894.

Wu, L., Yu, Y. H., Zhang, T. L., Feng, W. S., et al. 2009: PCRDGGE fingerprinting analysis of plankton communities and its relationship to lake trophic status. Internat. Rev. Hydrobiol. 5, 528-541.

Wu, L., Ge, G., Zhu, G. F., Gong, S. J., et al. 2012: Diversity and composition of the bacterial community of Poyang Lake (China) as determined by $16 \mathrm{~S}$ rRNA gene sequence analysis. World J Microbiol. Biotechnol. 28, 233-244.

Yavitt, J. B., Yashiro, E., Cadillo-Quiroz, H., Zinder, S. H. 2012 Methanogen diversity and community composition in peatlands of the central to northern Appalachian Mountain region, North America. Biogeochemistry 109, 117-131.

Yu, S., Ehrenfeld, J. G. 2010: Relationships among plants, soils and microbial communities along a hydrological gradient in the New Jersey Pinelands, USA. Ann. Bot. 105, 185-196.

Zelles, L. 1997: Phospholipid fatty acid profiles in selected members of soil microbial communities. Chemosphere 35, 275-294.

Zelles, L. 1999: Fatty acid patterns of phospholipids and lipopolysaccharides in the characterisation of microbial communities in soil: A review. Biol. Fert. Soils. 29, 111-129.

Zogg, G. P., Zak, D. R., Ringelberg, D. B., MacDonald, N. W., et al. 1997: Compositional and functional shifts in microbial communities due to soil warming. Soil Sci. Soc. Am. J. 61, 475-481. 